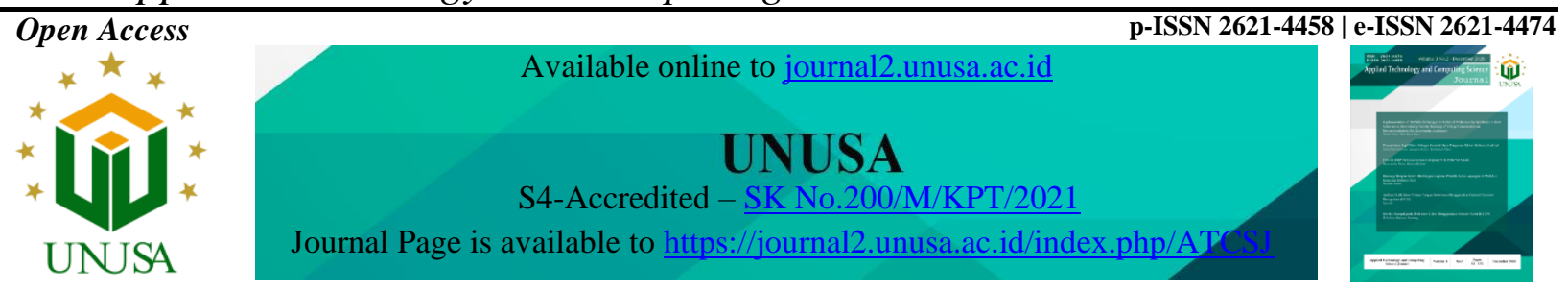

\title{
Online Presence System Development Website-Based using Prototype Methods
}

\author{
Muhammad Nur Faiz ${ }^{*}$, Nur Wahyu Rahadi², Nur Wachid Adi Prasetya ${ }^{3}$ \\ ${ }^{1,2,3}$ Teknik Informatika, Politeknik Negeri Cilacap, Indonesia \\ Jl.Dr.Soetomo No.1, Cilacap \\ 1*faiz@pnc.ac.id, ${ }^{2}$ n.wahyu.r@domain.ac.id, ${ }^{3}$ nwap.pnc@pnc.ac.id
}

Article history:

Received 10 May 2021

Revised 29 June 2021

Accepted 12 July 2021

Available online 31 July 2021

Keywords:

Online

Presence

Prototype

System

Website

\begin{abstract}
In the current era of the Covid-19 pandemic, almost all activities use technology, such as the lecture process. Nearly all of the lecturing processes in high education are carried out online to reduce the risk of contracting covid-19. The manual presences system by filling out forms or signatures is no longer effective because it has to be done offline. The online presence system is a system that is needed to find out about lectures, the discipline of teaching, and students. The method used in the development of this system is Prototype. This method has the advantage of paying close attention to user needs and a faster time for software development. The results of this study are a system for online presence in the era of the Covid-19 pandemic in real-time with photo evidence. Teaching can validate and change the presence of students. In addition, the admin can quickly recap the number of teaching and students' presences for reporting. Education also finds it helpful to take the results of student presences for reporting the completeness of the assessment data, and the head of the study program can see the presences summary report online. This system has been tested for functionality with an average result of $83.5 \%$ so that it can be said to be successfully built according to user needs.
\end{abstract}

\section{(ब) (ब)}

distribution, and reproduction in any medium, provided the original work is properly cited. (C2021 by author.

\section{INTRODUCTION}

The era of technology has become one of the milestones for the improvement of human civilization. very helpful for human activities. Technology has become very important in supporting activities in higher education, since the Covid-19 pandemic was declared in Indonesia, almost all community activities have been disrupted, including the teaching and learning process at universities[1]. The learning process in higher education is very dependent on the readiness of students and teaching to fulfil administration, such as presences lists. This presence is very important and must be monitored, especially by the campus [2]. Monitoring can be done through the form of the presence. Presences forms that have been printed have many shortcomings, including sometimes being lost, damaged, and fraudulent [3]. As of May 2, 2021, Indonesia registered 45,796 deaths from the coronavirus. The virus has a major impact on the economy, education, tourism, etc [4].

\footnotetext{
${ }^{*}$ Corresponding author
} 


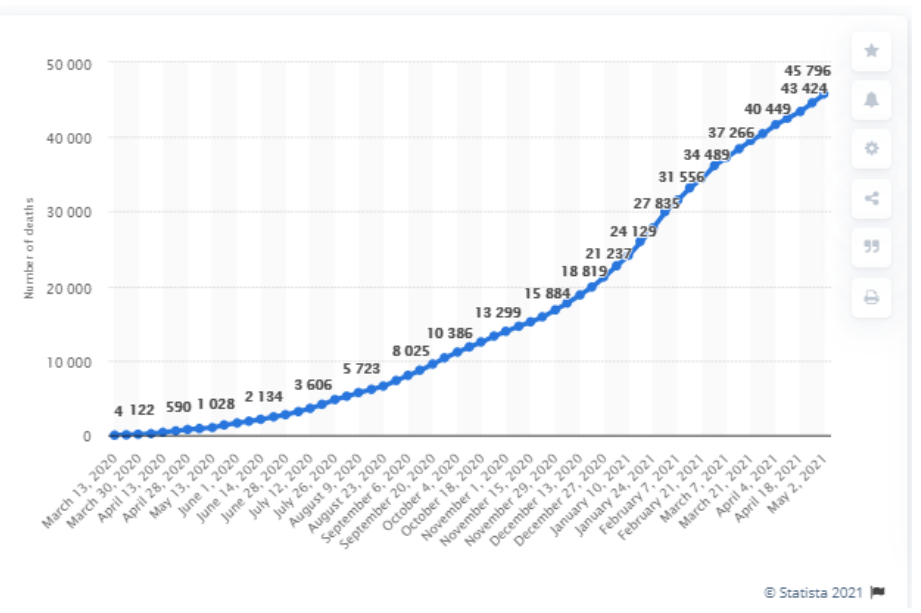

Figure 1. Total number of deaths from COVID-19 in Indonesia March 2020- May 2021

Lectures are currently conducted online so that students and teaching have an online presence. This presences activity is carried out for one semester then recapitulated by the academic party [5]. This process is ineffective because it allows errors and fraud. Recording and processing of presences data that is carried out continuously, recording is done every working day and reporting is called presences [6]. Website technology is a technology that allows users to search for information, conduct email transactions, communicate with instant messengers or social networks, shop through e-commerce websites [7],[8]. Website is the entire web page contained in a domain that contains the information [9] [10]. Commonly used web applications such as Mozilla Firefox, Google Chrome, Opera, Apple Safari and others [11].

\section{RELATED WORKS}

The research conducted by [12] resulted in the development of an android application using a spiral model with the feature of students being able to presences online in real-time and teaching being able to monitor and control the student presence process. Subsequent research conducted by [13] resulted in the design and implementation of the RFID (Radio Frequency Identification) auto presence system which is integrated with the web information system which was carried out experimentally. The study, entitled Android-Based Student presence Application. This study produces a presence Application that can monitor student presences levels and educate students for discipline. in addition, it also facilitates the homeroom teacher to process daily student presence and makes presence data recapitulation [5]. Research conducted by Reymon produces a presence system that can be used to obtain presence data for each presentation session at the conference [14]. Next research on the development of Honda Care software as a motorcycle maintenance application using the prototyping method with a case study on AHASS in Malang City by [15]. In the process, it was carried out 2 times. This research will produce a mobile application that is connected to an embedded system in the form of a vertical water float sensor and NodeMCU. Applications are tested on Motorcycle Owners with user acceptance testing. The test results were $86.3 \%$ for software engineering aspects, $89.7 \%$ for functionality aspects and $88.6 \%$ for visual communication aspects. These results indicate a very good acceptance from the User and will be used as a reference as evidence that the Honda Care application has been completed and can be accepted by the User.

Prototyping is a software development method, which is a physical model of the system's work and functions as an early version of the system. With this prototyping method, a system prototype will be produced as an intermediary for developers and users so that they can interact in the process of information system development activities. For the prototype making process to be successful, it is by defining the rules at an early stage, that is, the developer and the user must have an understanding that the prototype was built to define initial requirements. The prototype will be removed or added to its part so that it is by the planning 
and analysis carried out by the developer until the trial is carried out simultaneously along with the development process [16]. This research focuses on developing an online presence system using websitebased Prototyping methods.

\section{METHODS}

This research will use the system design method with the Prototype model. A prototype is a software design method that is widely used by developers to interact with customers during the system creation process and consists of 5 interrelated or influencing stages, namely as follows:

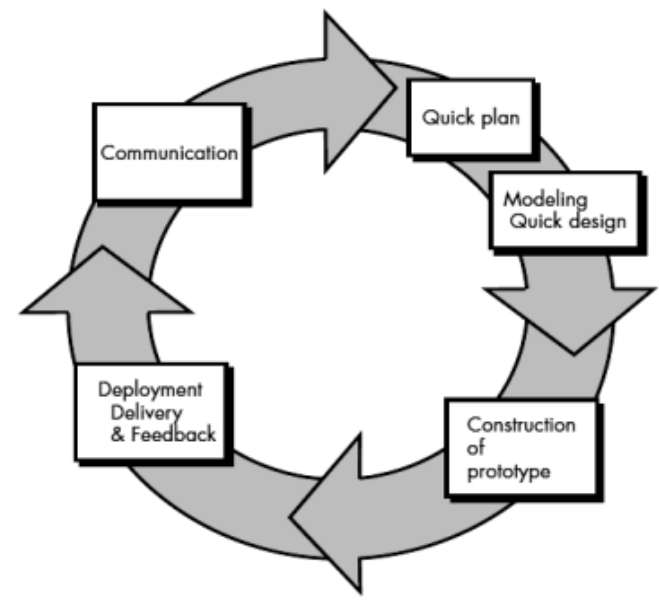

Figure 2. Prototyping Methods

Based on the prototype model described above, the discussion of each stage in the model can be described as follows:

1. Communication The software design team meets with stakeholders to determine software requirements that are currently known and to describe the area. -area where the definition is further for the next iteration.

2. Quick Plan / Quick Planning In this planning iteration of prototyping is done quickly. After that, modelling was carried out in the form of a "quick design".

3. Modelling Quick Design / Quick Design Model At this stage, planning to model is carried out in the previous stage using structured modelling in the form of DFD (Data Flow Diagram), ERD (Entity Relationship Diagram) and Flowchart to describe the analysis and system design

4. Construction of Prototype / Making Prototype In making a quick design based on the representation of aspects of the software that will be seen by end-users (e.g., user interface design or display format). Quick design is the basis for starting prototyping construction.

5. Deployment Delivery \& Feedback / Submission and Provide Feedback on Prototype Development then submitted to the stakeholders to evaluate the prototypes that have been made previously and provide feedback that will be used to improve requirements specifications. Iteration occurs when the developer makes improvements to the prototype. This research was carried out only up to the Construction of the Prototype stage in fast designing based on the representation of aspects of the Software at the end-user.

\section{RESUlts AND Discussions}

\section{A. Modelling}

The results and discussion in this research begin user analysis. Modelling database and system display are shown below. Use case diagram is a picture that is interconnected between actors and use cases in a system. This diagram is needed to model the process of a system according to the needs and expectations of users 
[17].

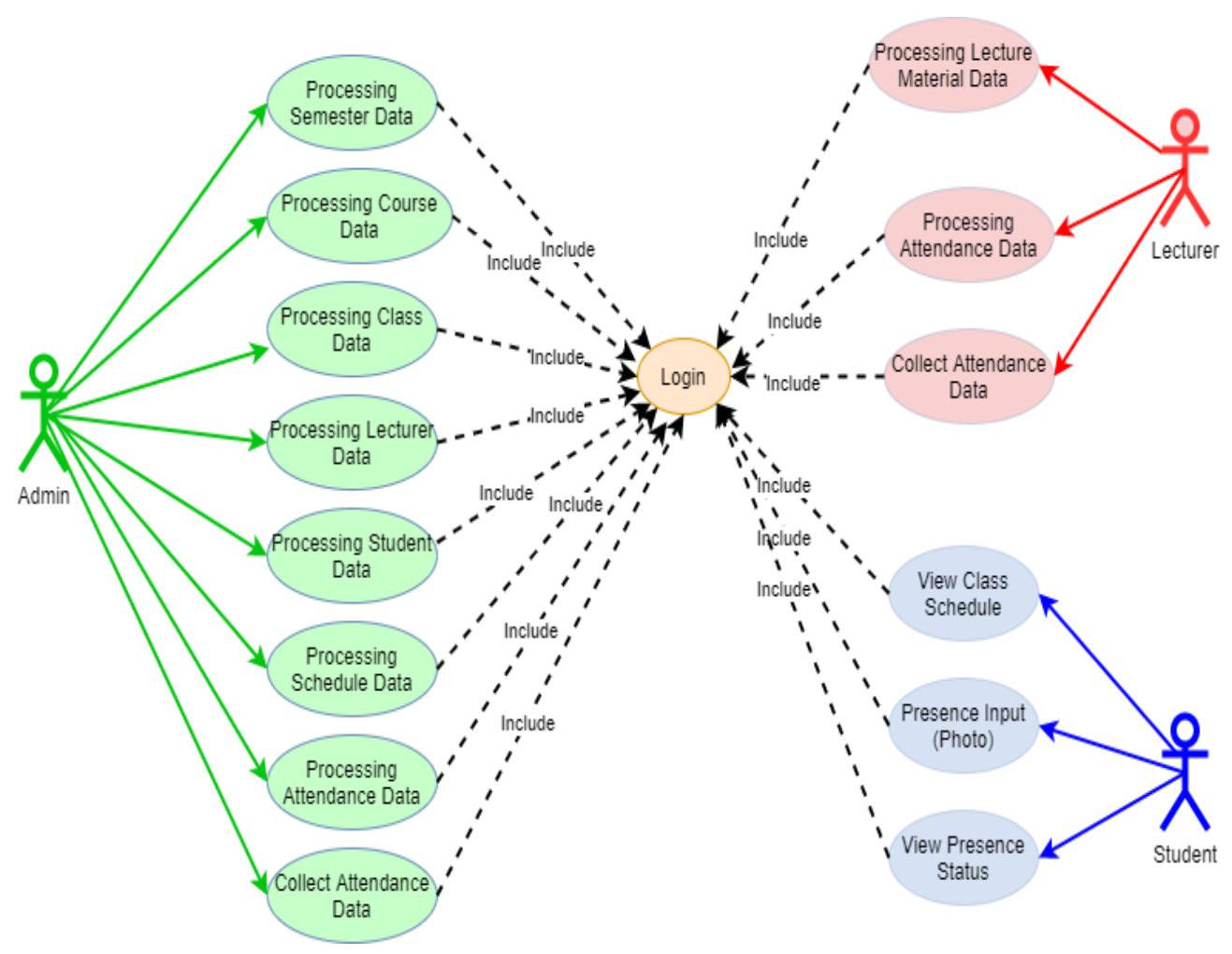

Figure 3. Use Case Design

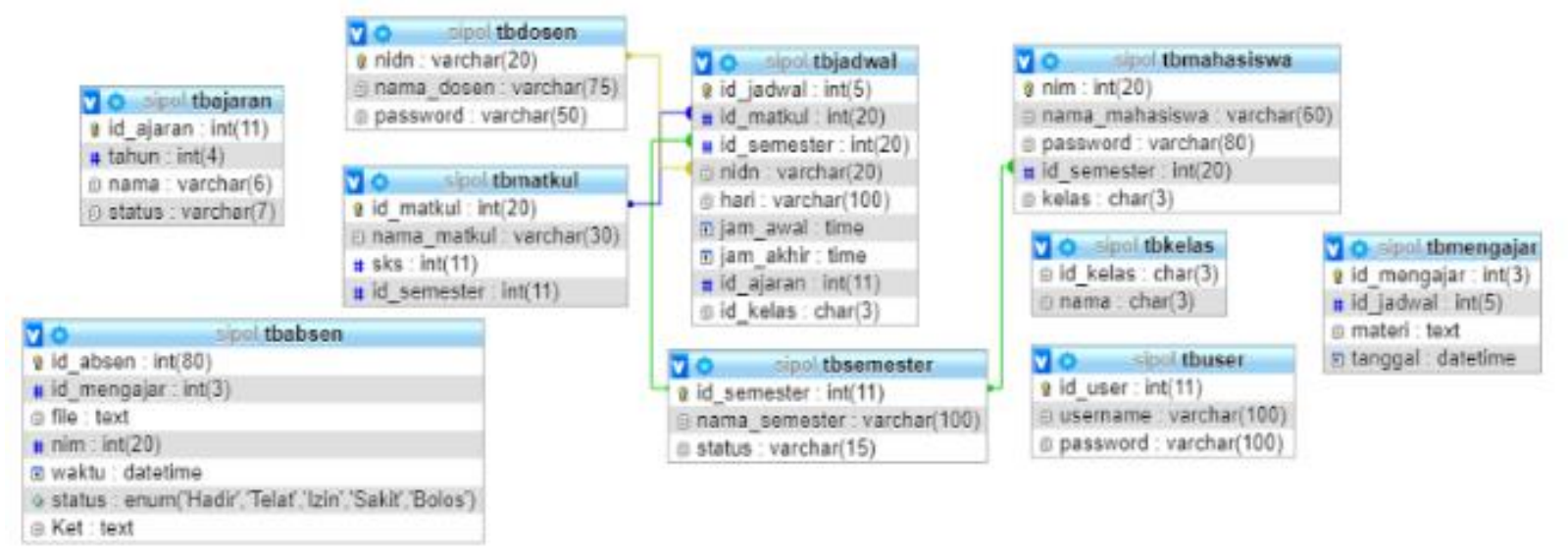

Figure 4. Database Design

In Figure 3 is a use case design that will be used as a guideline for system development, this use case clarifies the needs and functions of the user. In Figure 4 there are 10 entities or tables, bmahasiswa, tbdosen, tbajaran, tbabsen, tbsemester, tbmengajar, tbkelas, tbmatkul, tbjadwal, dan tb user. These entities are related to each other. 


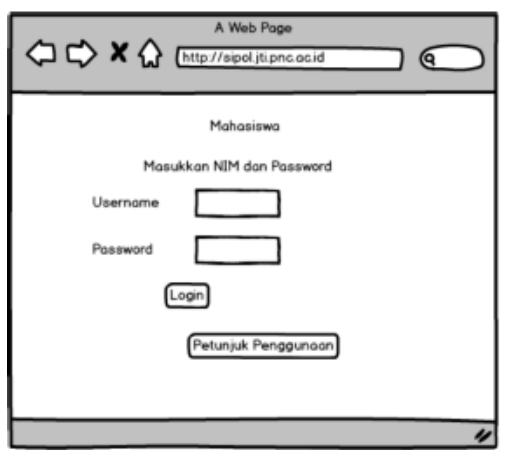

Figure 5. Design Login to System

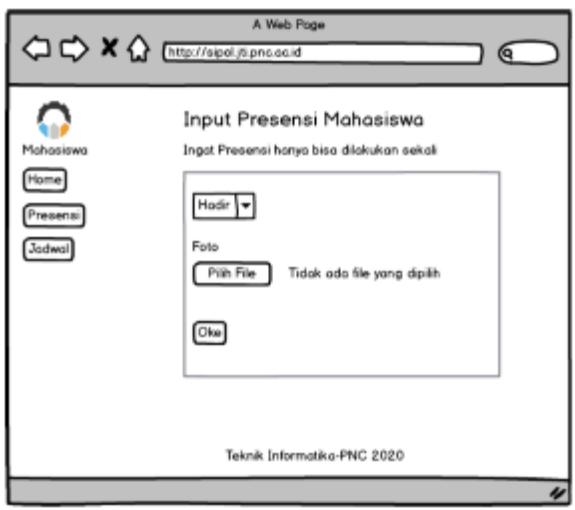

Figure 7. Presence Input Design

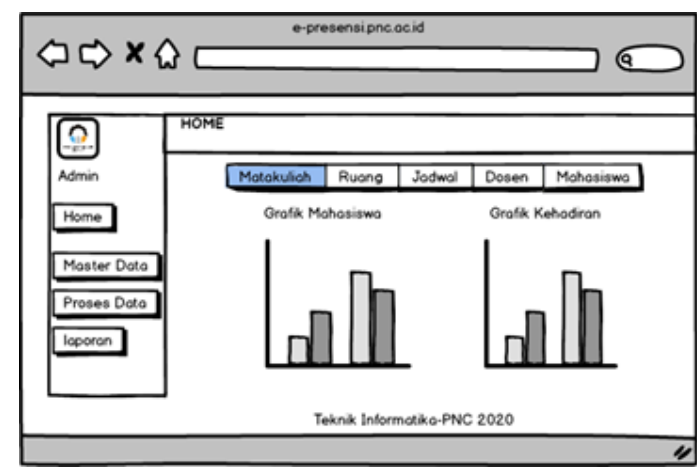

Figure 6. Dashboard Design

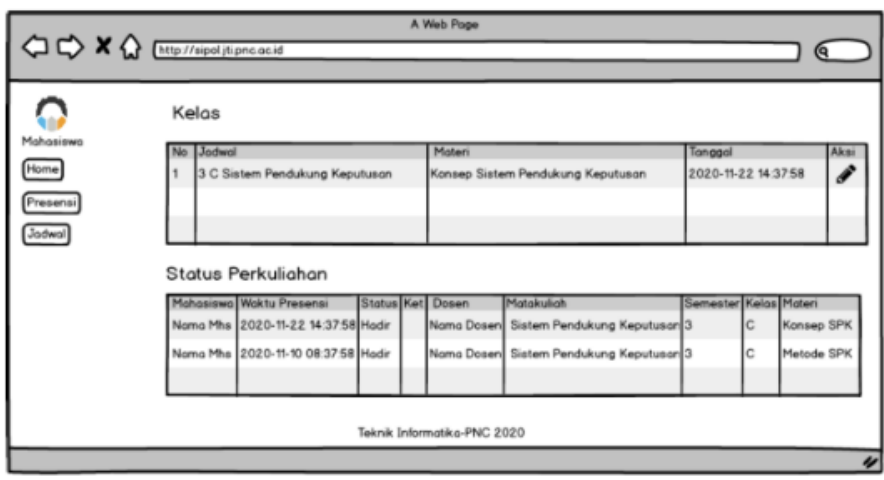

Figure 8. Design Successful Presence

Figure 5 is the login display design when the user will enter or first visit the system. Figure 6 is the design of the Dashboard display after the user has successfully entered the system. Figure 7 is the display design of the presences input when the user will perform presence by selecting courses, then making presence with selfies. Figure 8 is the display design after the student has succeeded in making an attendance. A table below appears with details with the time and selfies. Students can see firsthand whether the presence has been successful or not, the time and material being taught.

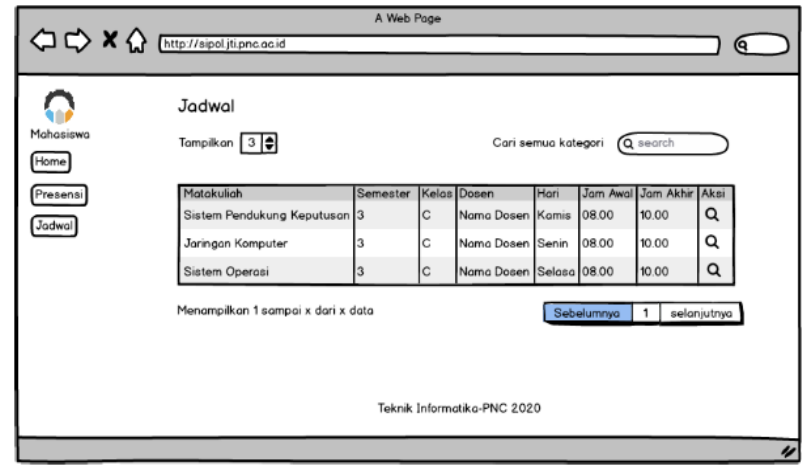

Figure 9. Schedule View Design

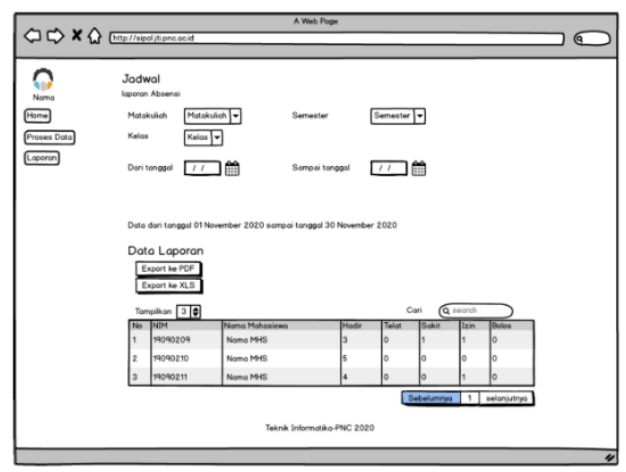

Figure 10. Presence Collect Display Design

Figure 9 shows the design of the lecture schedule that the student is participating in. Click details to see the material that has been taught. Figure 10 is the attendance collect display design that can be done by academics and lecturers. There is a time filter feature, courses and there is also export to PDF and Excel. 


\section{B. Constructions}

The next stage after modelling is the construction of the system. At this stage, the programmer plays an important role in reading the results of the modelling system. The following shows the display results of the system development.

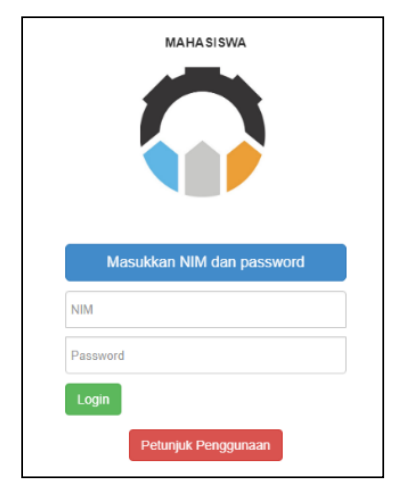

Figure 10. Login System

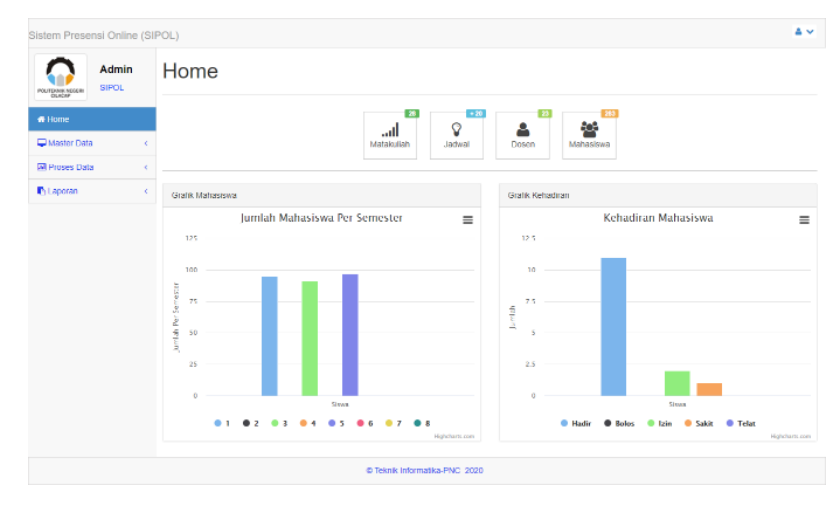

Figure 11. Dashboard Design

Figure 10 is the student login page. The login page for lecturers, admins and students with the same appearance. Students login using NIM for username, NIDN for lecturers. On that page there is a user guide button which contains the user guide. Figure 11 shows the admin dashboard page. On this Dashboard display, there is a quick menu, namely Matakuliah for courses, Jadwal for schedules, Dosen for lecturers and Mahasiswa for students that can be used to find out this information. On that page there is a graph that shows the number of students per semester and a graph of student attendance based on information such as attendance, lateness, permission, illness and absence.

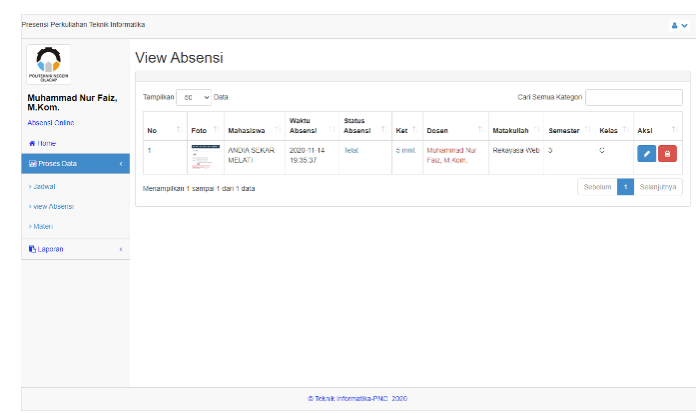

Figure 12. View Presence

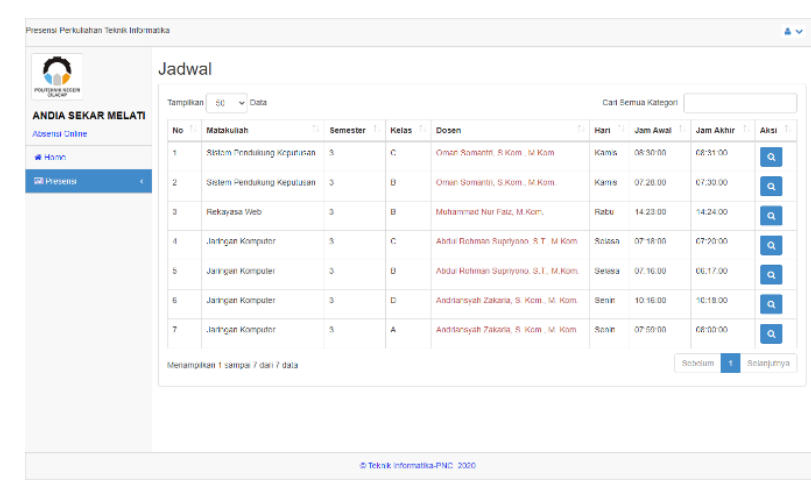

Figure 13. Schedule View

Figure 12 is a Display Page after students have successfully input their attendance, there is foto as a photos, Mahasiwa as a student name, waktu absensi as a presence time, ket as a description for attending, late, permission, sick, absent, Dosen as a lecturers, Matakuliah as a courses, Semester, Kelas for class. Figure 13 is a lecture schedule display consisting of No as number, Matakuliah as course name, semester, Kelas for class, Dosen as a lecturers, Hari as a Day, Jam Awal as a Start Hours, and Jam Akhir as a End Hours, Aksi as a Actions for look details. 


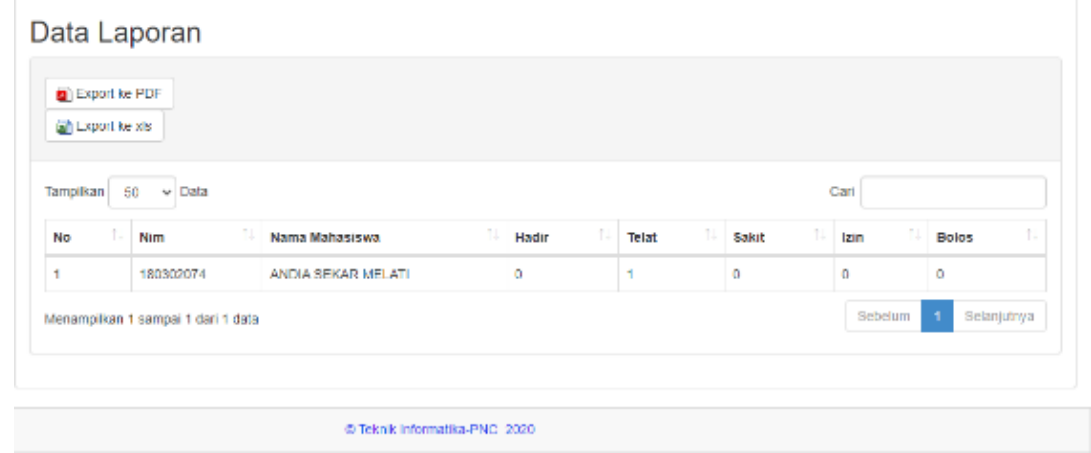

Figure 14. Presence Recap Display

In Figure 14 is a recap page of student attendance from the admin side. On that page there is a feature for reporting in excel and pdf formats to make it easier to make reports on student attendance in these courses and lecturers. On the page there is No as a number, Nim as a number identity for student, Nama mahasiswa as a student name, Hadir as a attending, Telat as a late, Sakit as a sick, Izin as a permission, and Bolos as an absent. Export ke PDF for report PDF format and Export xls for report Excel format.

\section{System Testing}

The next stage is system testing. This stage serves to determine the experience and whether it is in accordance with user needs or not. Questions based on the objectives of system development can be seen in table 1 using a Likert scale of 1-4. The results of this test are in the form of a satisfaction questionnaire on the use of the system built, whether it is in accordance with the needs or not. In addition, whether there are errors that occur in this assessment system as well as input and suggestions for system improvement. System testing is needed to involve many parties related to the system being built, especially those who have access to this system. From the sample used, the test results are obtained as shown in Figure 15.

Table 1. System Functional Testing Scenarios

\begin{tabular}{|c|c|}
\hline No & Testing Scenarios \\
\hline 1 & $\begin{array}{l}\text { The online presence system can } \\
\text { simplify lecture administration? }\end{array}$ \\
\hline 2 & $\begin{array}{l}\text { Online Presence system can improve } \\
\text { the discipline of lecturers and } \\
\text { students? }\end{array}$ \\
\hline 3 & $\begin{array}{l}\text { This online presence system is easy } \\
\text { to use? }\end{array}$ \\
\hline 4 & Is this system functioning properly? \\
\hline 5 & $\begin{array}{l}\text { This system can help lecturers and } \\
\text { students to know the schedule, } \\
\text { attendance, and materials? }\end{array}$ \\
\hline 6 & $\begin{array}{l}\text { Admins and heads of departments } \\
\text { can find out which lectures are } \\
\text { taking? }\end{array}$ \\
\hline 7 & $\begin{array}{l}\text { Does this system reduce presence } \\
\text { fraud? }\end{array}$ \\
\hline
\end{tabular}




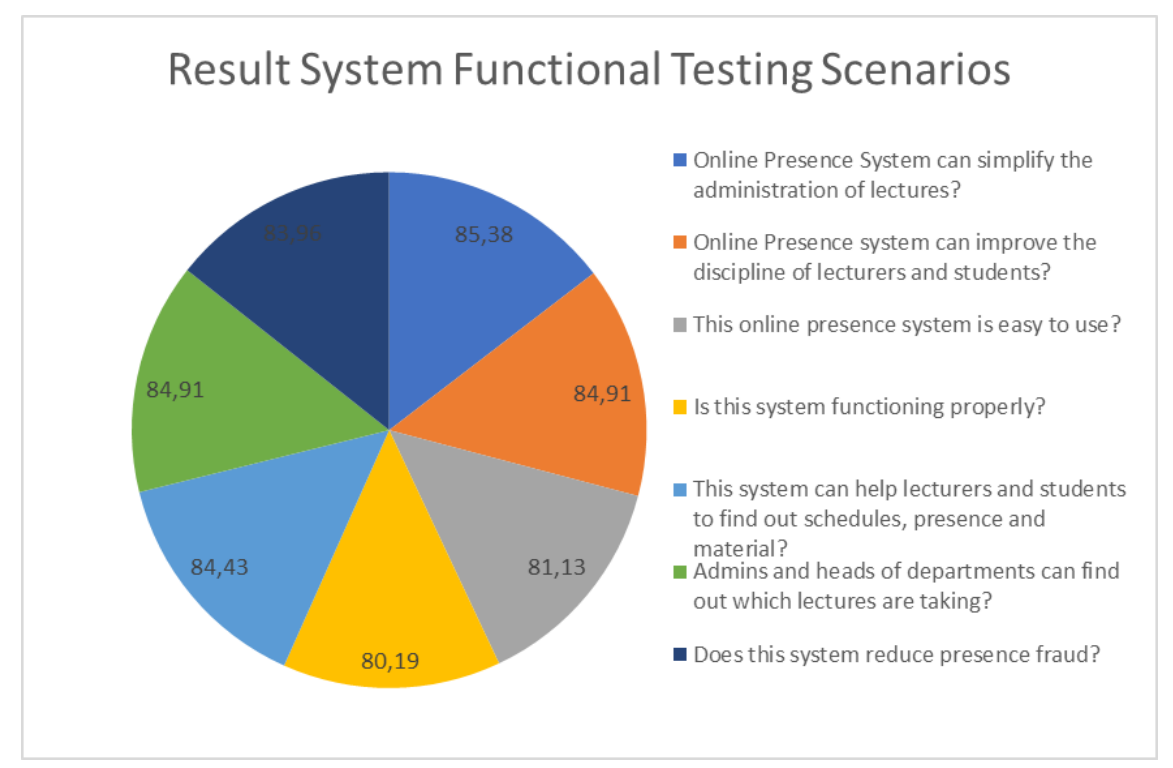

Figure 15. Results of the Functional Test Questionnaire

Based the results of these tests there are several notes that can be used as a basis for application of this system, whether it is ready or not ready to be applied. Analysis results the trial of this application obtained the following results;

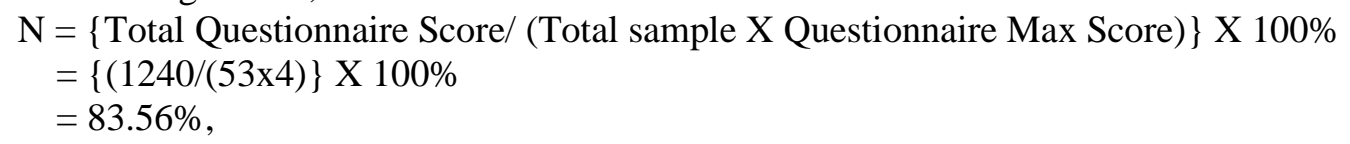

From the percentage of satisfaction that has been carried out when testing this system shows $83,6 \%$ shows that this system can be applied to help attendance at lectures during the covid-19 pandemic so that it can reduce paper use, leaders can directly monitor lecture activities, recap attendance more quickly. some comments are more about an unattractive appearance, a mobile version is made, added to the media used by lecturers in lectures such as Google meet, Zoom, E-learning, Edmodo etc.

\section{CONCLUSIONS AND RECOMMENDATIONS}

Based on the research conducted, the system developed can make it easier to recap teaching journals and presences data in real-time. Lecturers can start teaching whenever and wherever, according to the agreement with students, the material that has already been taught can be seen. This research also makes it easier for students to do presences anywhere. Students can see the presences status, the number of meetings and material taught by the lecturer, and students' teaching schedule. This research is also so that the Academic unit can monitor lectures directly and recapitulate them more quickly and accurately, and then the teaching is well documented so that it can be used for accreditation and other things. Recommendations for further research are online presences applications based on android and integrated directly with the campus Academic System.

\section{REFERENCES}

[1] N. F. Muchlis, "Monitoring Keaktifan Mahasiswa Selama Perkuliahan Online Pada Masa Pandemi Covid-19 Melalui Aplikasi Absensi Dan Penilaian Berbasis Mobile," JIRA J. Inov. dan Ris. Akad., vol. 1, no. 4, pp. 350-359, 2020, doi: 10.47387/jira.v1i4.59.

[2] A. Rifai, D. Yunika, and H. Novianti, "Perancangan Sistem Presensi Mahasiswa Berbasis Online," in Prosiding Annual Research Seminar, 2017, vol. 3, no. 1, pp. 191-193. 
[3] M. Olivya and R. Praminasari, "PERANCANGAN APLIKASI ABSENSI PERKULIAHAN MENGGUNAKAN TEKNOLOGI NEAR FIELD COMMUNICATION," in Prosiding Seminar Hasil Penelitian (SNP2M) 2018, 2018, vol. 2018, pp. 219-224.

[4] H. Nurhayati-Wolff, "Total number of deaths from COVID-19 Indonesia 2021," Statista, 2021. .

[5] R. Firliana and F. Rhohman, "Aplikasi Sistem Informasi Absensi Mahasiswa dan Dosen," J. Comput. Inf. Technol., vol. 2, no. 2, pp. 70-74, 2019.

[6] N. L. Khoiriyah, F. Marisa, and I. D. Wijaya, "Rancang Bangun Sistem Presensi Online Berbasis Granted Validitas Data," J I M P - J. Inform. Merdeka Pasuruan, vol. 3, no. 1, pp. 53-61, 2018, doi: 10.37438/jimp.v3i1.89.

[7] M. F. Sidiq and M. N. Faiz, "Review Tools Web Browser Forensics untuk Mendukung Pencarian Bukti Digital," J. Edukasi dan Penelit. Inform., vol. 5, no. 1, p. 67, Apr. 2019, doi: 10.26418/jp.v5i1.31430.

[8] M. Khairi, "Rancang Bangun Sistem Bimbingan Laporan Praktek Kerja Lapangan di SMKN 2 Kraksaan Berbasis Web," Appl. Technol. Comput. Sci. J., vol. 3, no. 2, pp. 91-102, 2021, doi: 10.33086/atcsj.v3i2.1869.

[9] I. Chaidir, D. W. Aditya, and S. Sumarna, "Rancang Bangun Sistem Informasi Perpustakaan Berbasis Web Pada Mts Al - Husna Depok," J I M P - J. Inform. Merdeka Pasuruan, vol. 5, no. 2, pp. 36-40, Jan. 2020, doi: 10.37438/jimp.v5i2.270.

[10] N. Chasanah, P. D. Abda'u, and M. N. Faiz, "Implementasi Metode Waterfall dalam Sistem Informasi Knowledge Management untuk Digital Marketing," Infotekmesin, vol. 12, no. 1, pp. 71-80, 2021, doi: 10.35970/infotekmesin.v12i1.363.

[11] R. Umar, A. Yudhana, and M. N. Faiz, "Experimental analysis of web browser sessions using live forensics method," Int. J. Electr. Comput. Eng., vol. 8, no. 5, pp. 2951-2958, 2018, doi: 10.11591/ijece.v8i5.pp.29512958.

[12] A. F. Andini, M. Irzal, and R. Arafiyah, "PERANCANGAN DAN IMPLEMENTASI SISTEM ABSENSI ONLINE BERBASIS ANDROID DI LINGKUNGAN UNIVERSITAS NEGERI JAKARTA," Sist. Inf., vol. 1, no. 1, pp. 1-10, 2017.

[13] A. Jadid, Zulhelmi, and Ardiansyah, "Rancang Bangun Sistem Absensi Perkuliahan Auto Id Berbasis Rfid Yang Terintegrasi Dengan Database Berbasis Web," J. Karya Ilm. Tek. Elektro, vol. 2, no. 2, pp. 59-69, 2017.

[14] R. Rotikan, "Sistem Informasi Absensi Berbasis Web Untuk Kegiatan Konferensi Web-Based Information System Attendance to Activity Conferences," J. Ilm. Sisfotenika, vol. 6, no. 1, pp. 46-55, 2016, doi: http://dx.doi.org/10.30700/jst.v6i1.104.

[15] W. G. Pradita, A. H. Brata, and M. T. Ananta, "Pembangunan Aplikasi Honda Care sebagai Sistem Perawatan Sepeda Motor menggunakan Metode Prototyping ( Studi Kasus pada AHASS di Kota Malang )," J. Pengemb. Teknol. Inf. dan Ilmu Komput., vol. 2, no. 12, pp. 6306-6314, 2018.

[16] D. Purnomo, "Model Prototyping Pada Pengembangan Sistem Informasi," J I M P - J. Inform. Merdeka Pasuruan, vol. 2, no. 2, pp. 54-61, 2017, doi: 10.37438/jimp.v2i2.67.

[17] A. Homaidi and A. Lina, "Pengembangan Sistem Informasi Manajemen Berbasis Web dalam Rangka Mendukung Evaluasi Kinerja Akademik dan Dosen di Akademi Manajemen Informatika dan Komputer Ibrahimy," Appl. Technol. Comput. Sci. J., vol. 2, no. 1, pp. 25-38, 2019, doi: 10.33086/atcsj.v2i1.1125. 